\title{
Correction to: The Hidden Dimensions of Human-Technology Relations
}

\author{
Scott T. Luan ${ }^{1}$ \\ Published online: 17 August 2019 \\ (C) Springer Nature B.V. 2019
}

\section{Correction to: Philosophy \& Technology https://doi.org/10.1007/s13347-019-00349-8}

The original version of this article unfortunately contains an incorrect sentence.

The first sentence of the 2 nd paragraph on page 8 should be

In Lifeworld, the touchstone in Ihde's elucidation of alterity relations is the selfregulating machine.

The original article has been corrected.

Publisher's Note Springer Nature remains neutral with regard to jurisdictional claims in published maps and institutional affiliations.

The online version of the original article can be found at https://doi.org/10.1007/s13347-019-00349-8

Scott T. Luan

scottlua@buffalo.edu

1 Department of Philosophy, University at Buffalo, SUNY, 135 Park Hall, Buffalo, NY 14260, USA 